\title{
A comparison of leadership styles with respect to biographical characteristics
}

\begin{tabular}{|c|c|}
\hline $\begin{array}{l}\text { Authors: } \\
\text { Javad Afshari } \\
\text { Zahra Moein }{ }^{1} \\
\text { Farzad Afshar } \\
\text { Javad Sharifi- } \\
\text { Abbas Balouc } \\
\text { Azam Afshari }\end{array}$ & 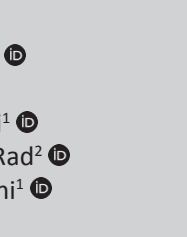 \\
\hline $\begin{array}{l}\text { Affiliations: } \\
{ }^{1} \text { College of } \mathrm{N} \\
\text { Midwifery, Za } \\
\text { of Medical Sc }\end{array}$ & $\begin{array}{l}\text { Irsing and } \\
\text { bol University } \\
\text { ences, Iran }\end{array}$ \\
\hline $\begin{array}{l}{ }^{2} \text { Phytochemis } \\
\text { Center, Shahi } \\
\text { University of } \\
\text { Sciences, Iran }\end{array}$ & $\begin{array}{l}\text { try Research } \\
\text { Beheshti } \\
\text { Medical }\end{array}$ \\
\hline $\begin{array}{l}\text { Correspondin } \\
\text { Zahra Moein, } \\
\text { zm253545@g }\end{array}$ & $\begin{array}{l}\text { g author: } \\
\text { mail.com }\end{array}$ \\
\hline $\begin{array}{l}\text { Dates: } \\
\text { Received: } 14 \\
\text { Accepted: } 22 \\
\text { Published: } 12\end{array}$ & $\begin{array}{l}\text { May } 2016 \\
\text { Nov. } 2016 \\
\text { Apr. } 2017\end{array}$ \\
\hline $\begin{array}{l}\text { How to cite th } \\
\text { Afshari, J., Mo } \\
\text { F., Sharifi-Rad, } \\
\text { \& Afshari, A. ( } \\
\text { comparison of } \\
\text { styles with res } \\
\text { biographical c } \\
\text { SA Journal of } \\
\text { Management } \\
\text { Menslikehulpk } \\
\text { 15(0), a817. h } \\
\text { org/10.4102/s } \\
\text { v15i0.817 }\end{array}$ & $\begin{array}{l}\text { is article: } \\
\text { ein, Z., Afshari, } \\
\text { J., Balouchi, A., } \\
\text { 2017). A } \\
\text { f leadership } \\
\text { pect to } \\
\text { haracteristics. } \\
\text { Human Resource } \\
\text { /SA Tydskrif vir } \\
\text { ronbestuur, } \\
\text { ttps://doi. } \\
\text { ajhrm. }\end{array}$ \\
\hline $\begin{array}{l}\text { Copyright: } \\
\text { ( ) 2017. The } \\
\text { Licensee: AOS } \\
\text { is licensed un } \\
\text { Creative Com } \\
\text { Attribution Lic }\end{array}$ & $\begin{array}{l}\text { uthors. } \\
\text { IS. This work } \\
\text { der the } \\
\text { nons } \\
\text { ense. }\end{array}$ \\
\hline Read online: & \\
\hline 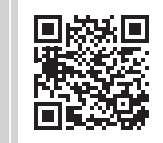 & $\begin{array}{l}\text { Scan this QR } \\
\text { code with your } \\
\text { smart phone or } \\
\text { mobile device } \\
\text { to read online. }\end{array}$ \\
\hline
\end{tabular}

Authors:

Farzad Afshari ${ }^{1}$

Javad Sharifi-Rad ${ }^{2}$

Abbas Balouchi ${ }^{1}$ (D)

Afshari

Midwifery, Zabol University

${ }^{2}$ Phytochemistry Research Center, Shahid Behesht

University of Medical

Corresponding author:

Zahra Moein,

Dates:

Received: 14

Accepted: 22 Nov. 2016

How to cite this article:

Afshari, J., Moein, Z., Afshari,

F., Sharifi-Rad, J., Balouchi, A.

\& Afshari, A. (2017). A

biographical characteristics.

SA Journal of Human Resource

Menslikehulpbronbestuur,

15(0), a817. https://doi.

org/10.4102/sajhrm.

Copyright:

(C) 2017. The Authors

Licensee: AOSIS. This work

commons

mobile device
Research purpose: Managers, when applying their leadership styles, are affected by some of their own traits. This article intends to compare the leadership styles of the managers of Zabol University of Medical Sciences with respect to Hersey and Blanchard model that was based on their biographical characteristics.

Research design, approach and method: The research methodology is descriptive-causal and comparative. The data were collected from 300 individuals (124 female and 176 male participants).

Main findings: No significant difference was observed between the directive, persuasive, participative and delegative leadership styles of male and female managers. However, there was a significant difference between the mean of the directive, persuasive, participative and delegative leadership styles of managers, considering their work experience, education level and field of study.

Research limitations: The conservative atmosphere in university environments may affect the manager's responses to the questionnaire; therefore, in the generalisation of the results, this issue should be taken into account.

Practical implications: It is recommended to hold in-service courses for managers who have a lower education level or less work experience or have been graduated from the fields of study other than the Management major. It is also suggested to pay attention to the managers' fields of study and managerial experiences at the time of employment.

Contribution: This study enhances the quality of managers' leadership style and consequently increases the productivity in university environments.

\section{Introduction}

Many experts in management and organisation believe that leadership style is one of the most important elements in the managers' success, which can be gradually established based on their experience, education, training and the system of values and beliefs (Hersey \& Blanchard, 2005). Many experts and scholars believe that if there is to be only one factor to distinguish between successful and unsuccessful organisations, that factor will be the dynamic and effective leadership (Mirsepasi, 2005).

Considering the role of education in the progress and development of a country, organisational managers, particularly university managers, can interact with their subordinates through selecting the appropriate leadership style and recognising all the factors effective in the education process and university management. They can also provide the context for an effective implementation of plans and achievement of goals through enhancing the employees' morale and making them connected to vocational and personal objectives and motivating them to work; thereby, managers will be able to successfully accomplish educational activities and provide a desirable productivity in their employees. Evidently in organisations, where managers do not select an appropriate leadership style, there will be a conflict among the employees. The organisation's atmosphere will be tedious and employees will despise it, and consequently, the organisation's efficiency will be decreased (Khalkhali, Shakibaei \& Andesh, 2011).

An effective leadership style is selected according to the different conditions, about which a capable manager should have a rich understanding in order to exploit them to their best advantage. University managers are in contact with the special people, who demand a particular type of management. In general, an individual's leadership style is defined by his or her behavioural pattern for influencing others' activities; this type of leadership is a combination of task orientation 
and relationship orientation. These two types of advocating task and advocating relationship are among the main components of leadership styles (Robinson, 2010).

The importance of leadership in organisations has caused thinkers and scholars of management to attempt to discover the features and characteristics of successful managers in organisations and always try to specify the characteristics in organisations. Previous research results indicate that managers' use of different leadership styles varies considerably. In this regard, Van Engen and Willemsen (2004) and Kolaric (2005) separately presented different results about the managers' selection method for leadership styles. Their research results showed that there are different relationships between the managers' leadership styles and some of their personal traits.

Davis (2002), while studying the managers' leadership style, obtained the following results: whereas only $28.9 \%$ of managers used the evolutionary leadership style, $62.7 \%$ of educators applied the evolutionary leadership style. In addition, he realised that there is no significant relationship between the leadership style and the years of experience. Added to that, there is no meaningful relationship between the leadership style and the education level.

Gharaeini and Abbaszadeh (2009) comprehended that there is a significant difference between the leadership style of male and female managers, and male managers use the relationship-oriented style more than female managers; but the leadership styles of managers, in accordance with their education level, were identical and no significant difference was noticed.

Khaksar (2002) concluded that there is no significant relationship between the effective behaviour of managers in boys' and girls' schools. Mahboudi (2006) showed that there is a meaningful difference between the education level and the field of study of managers and their effectiveness; however, no significant difference was observed between the effectiveness of male and female managers. Sheikh Nezami (1997) conducted a study on school managers and concluded that female managers, compared to male managers, have more communication skills, but this difference was insignificant. In a study, entitled 'A comparison of the performance of managers, graduated from the Management major and the other fields, in the high schools of Mashhad city', Ziraki (1997) expressed that managers, graduated from the management and educational administrative planning majors, compared to their counterpart, have a better performance in skills such as exploiting resources, taking decisions, innovation and accountability.

Hamidi and Shoghli (2006) found that there is no significant difference between managers, graduated from the Management major and those graduated from the other fields of study, in nine main roles, including evaluation, group leadership, organisation, teachers' consultation, coordination, administrative planning, decision making, service provision, management and supervision. Ettehadnejad (2001) concluded that from the teachers' perspective, the education level, field of study and management experience are not influential on their effective skills; however, in teachers' view, there exists a significant difference between male and female managers in the domain of professional, technical, perceptional and human effective skills (Wafa, Ramaya \& Hoon, 2005). Wafa, in his study on the leaders' behaviour and the leadership effectiveness, which was carried out among the high school managers, perceived that there is a significant difference between the teachers' viewpoint about the leadership effectiveness of male and female managers; however, no significant relationship was reported between the race, field of study, and education level of managers and the managers' effectiveness. Robinson (1996) spotted a significant difference when comparing the teachers' viewpoint on the leadership effectiveness of the elementary school managers based on their age, gender and ethnicity. Jafari and Yousefnejad (2002) indicated that there is no significant difference between the leadership style of male and female managers, whereas Hyler Linda (1993) showed that there is a difference between the leadership style of male and female managers.

\section{Research theoretical framework The concept of leadership}

There are different definitions for leadership, each of which clarifies an aspect of the leadership operation and process. In this article, it has been attempted to state different definitions in order to achieve a more thorough understanding. Leadership is defined as the ability to influence the group and direct it towards the intended goals. It is a source of the influencing power and has an official nature, like leaning on the bench of management. Furthermore, it is worth stating that not all leaders are managers and not all managers are leaders (Robinson, 2010). Leadership is a structured unit, consisting of the current needs. In leadership, participation is the key and the most important aspect. Moreover, identifying the weaknesses, strengths, threats and opportunities is an indispensable element for leadership. The leader gives feedbacks about his or her daily jobs and will be the pioneer, whenever necessary (Bennis, 1999).

\section{Leadership style}

Hersey and Blanchard believe that personality and style are synonyms and in their view, one's personality or style is defined as the behavioural pattern she or he shows when directing the activities of others (Alagheband, 2006). Considering the variable nature of human behaviours in different conditions, it can be realised that the leadership style or method is variable and one single style cannot be adopted in all conditions for all institutions and organisations. Therefore, a manager's leadership style is to be related to his or her assumptions about the human's nature and the people in the organisation with whom she or he works. Every manager has some assumptions about the nature of the people around him, such as the subordinates, peers and 
bosses. These assumptions consciously or unconsciously affect his or her decisions, behaviours and in general his or her style (Griffin \& Moorhead, 2011).

\section{Hersey and Blanchard's situational theory}

Situational leadership is a contingency theory, which concentrates on the followers and subordinates of a leader. The goal of this focus is related to this fact that a leader's success and effectiveness originally result from the followers, who accept or reject him or her. Regardless of what a leader does, his or her success rate depends on his or her followers' reaction. The method, presented by Hersey and Blanchard, is based on the maturity level or the readiness level of followers. In general, readiness reflects how much ability and willingness a follower has for performing a task. Hersey and Blanchard specified four stages for obtaining this readiness:

- In the first stage, individuals are neither willing, nor able to take the responsibility of performing a task.

- In the second stage, individuals are not able to perform the tasks, but they are ready and willing to take the responsibility.

- In the third stage, individuals have the ability to do the tasks, but they are not willing to do what the leader says.

- In the fourth stage, individuals have the ability and willingness to do what they are asked to do (Hersey \& Blanchard, 2005).

Situational leadership applies the two dimensions, specified by Fiedler; that is, the leader's behaviour according to the focus on the task or on the employee. Hersey and Blanchard have gone further and placed each dimension in one end of the spectrum and then four special leadership styles were created by integrating them:

- Directing (more attention to work - less attention to employee): the leader defines the tasks and tells the employees how, when and where to perform what task. In this method, the instructions are much focused.

- Persuasion (more attention to work - more attention to employee): the leader continues giving instructions in order to make the individual more familiar to his or her tasks; but the leader's attention to the person him or herself has increased.

- Participation (less attention to work - more attention to employee): the leader and follower both participate in the decision-making process. The main role of the leader is to increase the pace of performing tasks and the communication speed.

Delegation (less attention to work - less attention to employee): the leader gives no instruction or directive about the task or for the sake of supporting the employees (Mirsepasi, 2005). When the followers are at a high level of readiness, the leader not only lessens his or her control on the tasks but also attempts to reconsider his or her behaviour and in other words supports the employees less than before. For example, in the first stage of readiness, the leader should give clear instructions to his or her followers, such as the instructions presented by the directive leadership style. In the second stage, the leader should pay much more attention to task and employees. By focusing more on the task, the employees' lack of readiness and ability will be compensated, and by focusing more on employees, they will also attempt to mentally compensate the leader's favours and fulfil his or her demands. In the third stage, the motivational issues are raised, which will be solved in the best way in the participative leadership style. Finally, in the fourth stage, the leader should not do much work because the followers are willing and able to take the responsibilities (Robinson, 2010).

\section{The necessity of the leadership style for managers}

Many experts of management and organisation believe that leadership style is one of the most important elements in the success of managers, which is gradually established based on their experience, education, training and the system of values and beliefs (Hersey \& Blanchard, 2005). The leadership style and the decisions taken by managers affect the organisation's performance from top to bottom. This factor leads to the organisation's success or failure because in addition to the other internal factors of the organisation's atmosphere, it also affects and controls the external factors (Khalkhali et al., 2011).

\section{Research methodology}

The present article is a descriptive-comparative study. The data collection method is the library-field method. Statistical population of this research includes the male and female managers and employees at Zabol University of Medical Sciences. The number of managers is 52 (12 women and 40 men) and the number of employees is 1300 (537 women and 763 men). The sample size for managers is 52 individuals, determined by census; and the sample size for employees is 300 individuals including 124 females and 176 males, determined by the stratified random sampling based on the Morgan table. In order to evaluate the leadership style, 40 managers with 6 employees from their subset, and 12 managers with 5 employees from their subset were selected. In order to gather the required information, two questionnaires were used as follows:

- Demographic information questionnaire, including gender, age, education level, field of study, and work experience.

- Leadership style questionnaire: in order to evaluate the leadership style, the leadership effectiveness and adaptability description questionnaire, based on the situational leadership theory of Hersey and Blanchard, was used. The questionnaire consists of 12 questions, which measure the four leadership styles of directive, persuasive, participative and delegative. With a 4-scale ranking, this questionnaire has been set with the priorities $1-4$. It is worth mentioning that the content validity of this questionnaire has been previously determined in the Iranian society with the reliability coefficient of 0.92 in Hasanian (2004) and 0.76 in Nooraee et al. (2006). 
In this study, in order to confirm the reliability of the questionnaire, 25 questionnaires were distributed among the employees of Zabol University of Medical Sciences, and after collecting them, the Cronbach's alpha coefficient was obtained 0.84; therefore, the reliability of the questionnaire was confirmed. The questions and the reliability coefficient of each style in the questionnaire are presented in Table 1.

Each individual's score is calculated on the whole scale as follows: if the questionnaire scores are between 12 and 24, the application of the directive, persuasive, participative and delegative leadership styles is at a weak level; if it is between 25 and 36, it is at an average level; and if it is higher than 37, the application of the directive, persuasive, participative and delegative leadership styles is a very high level.

\section{Findings}

The first hypothesis:

- Hypothesis 1: There is a difference between the leadership style of male and female managers.

Independent $t$-test was used to study the difference between the leadership style of male and female managers. The results are presented in Table 2 .

TABLE 1: The questionnaire items and reliability coefficients.

\begin{tabular}{llc}
\hline Styles & Question numbers & Reliability coefficient \\
\hline Directive & Options a, Q1 to Q12 & 0.80 \\
Persuasive & Options b, Q1 to Q12 & 0.73 \\
Participative & Options c, Q1 to Q12 & 0.75 \\
Delegative & Options d, Q1 to Q12 & 0.81 \\
\hline Total & - & $\mathbf{0 . 8 4}$
\end{tabular}

Findings of Table 2 show that no significant difference was observed between the directive, persuasive, participative and delegative leadership styles of male and female managers, at the confidence level of $95 \%$ and with the $t$-test values of $1.47,1.04,0.29$ and 0.21 , respectively $(p<0.05, d f=51)$.

The second hypothesis:

- Hypothesis 2: There is a difference between the managers' leadership style, with respect to their education level.

One-way analysis of variance was used to study the difference between the managers' leadership style with respect to their education level. The results are presented in Table 3.

According to Table 3, in the directive style, based on the findings of the one-way analysis of variance and the observed $F$, with regard to the comparison of the average scores of managers and with respect to their education level, no significant difference was observed at the confidence level of $95 \%$ ( $p \leq 0.05, F=1.95)$. In the persuasive style, with regard to the difference in the average scores of managers, based on the findings of the one-way analysis of variance and the observed $F$, with respect to their education level, no significant difference was observed at the confidence level of $99 \%$ ( $p \geq 0.01, F=3.99)$. The highest average was obtained by the managers holding bachelor's degrees.

Moreover, in the participative style, considering the difference in the average scores of managers, based on the findings of the one-way analysis of variance and the observed $F$, with regard to their education level, a significant difference was observed at the confidence level of $95 \%(p \geq 0.05, F=3.46)$. The highest average was obtained by the managers with the degrees higher than the master's degree. In the delegative

TABLE 2: Studying the difference between the leadership style of male and female managers.

\begin{tabular}{|c|c|c|c|c|c|c|c|}
\hline Variable & Gender & Number & Average & Standard deviation & Degree of freedom & $t$-test & Significance level \\
\hline \multirow[t]{2}{*}{ Directive } & Female & 12 & 32.01 & 6.42 & 51 & 1.47 & 0.69 \\
\hline & Male & 40 & 33.08 & 6.01 & & & \\
\hline \multirow[t]{2}{*}{ Persuasive } & Female & 12 & 16.45 & 4.81 & 51 & 1.04 & 0.55 \\
\hline & Male & 40 & 15.87 & 4.72 & & & \\
\hline \multirow[t]{2}{*}{ Participative } & Female & 12 & 25.70 & 8.43 & 51 & 0.29 & 0.85 \\
\hline & Male & 40 & 25.90 & 8.06 & & & \\
\hline \multirow[t]{2}{*}{ Delegative } & Female & 12 & 14.11 & 6.10 & 51 & 0.21 & 0.59 \\
\hline & Male & 40 & 14.32 & 6.44 & & & \\
\hline
\end{tabular}

TABLE 3: Results of the one-way analysis of variance of the thinking styles, with respect to the managers' education level.

\begin{tabular}{|c|c|c|c|c|c|c|c|}
\hline Variables & Degree & Number & Average & Standard deviation & Degree of freedom & $F$ & Significance level \\
\hline \multirow[t]{3}{*}{ Directive style } & Bachelor & 23 & 32.84 & 7.02 & 2 & 1.95 & 0.06 \\
\hline & Master & 21 & 32.04 & 5.59 & 49 & & \\
\hline & Higher than master & 8 & 32.70 & 6.55 & & & \\
\hline \multirow[t]{3}{*}{ Persuasive style } & Bachelor & 23 & 17.22 & 2.82 & 2 & 3.99 & 0.01 \\
\hline & Master & 21 & 15.92 & 4.98 & 49 & & \\
\hline & Higher than master & 8 & 16.60 & 5.04 & & & \\
\hline \multirow[t]{3}{*}{ Participative style } & Bachelor & 23 & 12.22 & 4.37 & 2 & 3.46 & 0.02 \\
\hline & Master & 21 & 14.23 & 7.21 & 49 & & \\
\hline & Higher than master & 8 & 14.95 & 4.03 & & & \\
\hline \multirow[t]{3}{*}{ Delegative style } & Bachelor & 23 & 19.40 & 5.72 & 2 & 3.81 & 0.01 \\
\hline & Master & 21 & 24.33 & 7.33 & 49 & & \\
\hline & Higher than master & 8 & 26.55 & 8.66 & & & \\
\hline
\end{tabular}


style, considering the difference in the average scores of managers, based on the findings of the one-way analysis of variance and the observed $F$, with regard to their education level, a significant difference was observed at the confidence level of $99 \%$ ( $p \geq 0.01, F=3.81)$. The highest average was obtained by the managers with the degrees, higher than the master's degree.

The third hypothesis:

- Hypothesis 3: There is a difference between the managers' leadership styles with respect to their work experience.

One-way analysis of variance was used to study the difference between the managers' leadership style with respect to their work experience. The results are presented in Table 4 .

The results of Table 4 with regard to the directive style of managers indicate that there is a significant difference between the managers' average years of work experience, at the confidence level of $99 \%(p<0.01, F=7.37)$. The highest average score was obtained by the managers with 1-10 years of work experience. Also, a significant difference with regard to the persuasive style of managers was observed between the managers' average years of work experience, at the confidence level of 99\% ( $p<0.01, F=6.82)$. The highest average score was obtained by the managers with $1-10$ years of work experience. Regarding the participative leadership style, a significant difference was observed between the managers' average years of work experience, at the confidence level of $95 \%(p<0.05, F=3.48)$. The highest average score was obtained by the managers with more than 20 years of work experience. Regarding the delegative leadership style, there is also a significant difference between the managers' average years of work experience, at the confidence level of $99 \%(p<0.01, F=4.54)$. The highest average score was obtained by the managers with more than 20 years of work experience.

The fourth hypothesis:

- Hypothesis 4: There is a difference between the managers' leadership style with respect to their field of study.

The independent $t$-test was utilised to study the difference between the managers' leadership style with respect to their field of study. The results are presented in Table 5 .

As can be seen in Table 5, a significant difference was observed between the average leadership style of the managers, graduated from the Management major and the other fields, at the confidence level of $99 \%(p<0.01, d f=50$, $t=3.17)$. The average score of the managers, graduated from the other fields is more than that of the managers, graduated from the Management major. Moreover, a significant difference was observed between the average score of the persuasive leadership style of the managers, graduated from the Management major and from the other fields, at the confidence level of $99 \%(p<0.01, d f=50, t=3.87)$. The average score of managers from the other fields is more than that of the managers from the Management major.

A significant difference was observed between the average score of the participative leadership style of the managers, graduated from the Management major and from the other fields, at the confidence level of $99 \%(p<0.01, d f=50, t=3.29)$. The average score of managers from the Management major is more than that of the managers from the other fields. Additionally, a significant difference was observed between the average score of the delegative leadership style of the

TABLE 4: Results of the one-way analysis of variance of leadership styles, with respect to the managers' work experience.

\begin{tabular}{|c|c|c|c|c|c|c|c|}
\hline Variables & Work experience & Number & Average & Standard deviation & Degree of freedom & $F$ & Significance level \\
\hline \multirow[t]{3}{*}{ Directive } & $1-10$ years & 24 & 31.40 & 4.98 & 2 & 7.37 & 0.00 \\
\hline & $11-20$ years & 17 & 28.44 & 5.57 & 49 & & \\
\hline & More than 20 years & 11 & 28.02 & 5.71 & & & \\
\hline \multirow[t]{3}{*}{ Persuasive } & $1-10$ years & 24 & 31.85 & 6.45 & 2 & 6.82 & 0.00 \\
\hline & $11-20$ years & 17 & 29.37 & 4.68 & 49 & & \\
\hline & More than 20 years & 11 & 28.37 & 6.49 & & & \\
\hline \multirow[t]{3}{*}{ Participative } & $1-10$ years & 24 & 29.27 & 5.24 & 2 & 3.48 & 0.03 \\
\hline & $11-20$ years & 17 & 29.88 & 8.21 & 49 & & \\
\hline & More than 20 years & 11 & 32.38 & 7.29 & & & \\
\hline \multirow[t]{3}{*}{ Delegative } & $1-10$ years & 24 & 32.34 & 6.11 & 2 & 4.54 & 0.00 \\
\hline & $11-20$ years & 17 & 32.01 & 6.18 & 49 & & \\
\hline & More than 20 years & 11 & 34.87 & 5.99 & & & \\
\hline
\end{tabular}

TABLE 5: Studying the difference between leadership styles, with respect to the managers' field of study.

\begin{tabular}{|c|c|c|c|c|c|c|c|}
\hline Variable & Field of study & Number & Average & Standard deviation & Degree of freedom & $t$-test & Significance level \\
\hline \multirow[t]{2}{*}{ Directive } & Management & 22 & 30.39 & 6.05 & 51 & 3.17 & 0.00 \\
\hline & Other majors & 30 & 33.68 & 6.65 & & & \\
\hline \multirow[t]{2}{*}{ Persuasive } & Management & 22 & 16.16 & 4.83 & 51 & 3.87 & 0.00 \\
\hline & Other majors & 30 & 18.23 & 4.61 & & & \\
\hline \multirow[t]{2}{*}{ Participative } & Management & 22 & 14.64 & 6.76 & 51 & 3.29 & 0.00 \\
\hline & Other majors & 30 & 12.16 & 4.56 & & & \\
\hline \multirow[t]{2}{*}{ Delegative } & Management & 22 & 25.99 & 8.45 & 51 & 4.21 & 0.01 \\
\hline & Other majors & 30 & 21.32 & 7.66 & & & \\
\hline
\end{tabular}


managers, graduated from the Management major and from the other fields, at the confidence level of $99 \%(p<0.01$, $d f=50, t=4.21$ ). The average score of managers from the Management major is more than that of the managers from the other fields.

\section{Discussion and conclusion}

In the present study, no significant difference was observed between the directive, persuasive, participative and delegate leadership styles of male and female managers. This finding conforms to the findings of Khaksar (2002), who concluded that there is no significant difference between the effective behaviour of managers in boys' and girls' schools. It is also in agreement with the study by Mahboudi (2006), who indicated that there is no meaningful difference between the effectiveness of male and female managers. It is also in conformity with the work of Sheikh Nezami (1997), who mentioned that female managers, compared to male managers, have better communication skills, but this difference is insignificant. However, the present article conclusion does not conform to the findings of Gharaeini and Abbaszadeh (2009), who comprehended that there is a difference between the leadership style of male and female managers, and also Wafa et al. (2005), who stated that there is a significant difference between the teachers' opinions on the leadership effectiveness of male and female managers. Furthermore, the findings of the second hypothesis showed that in the directive style, no significant difference was observed between the average scores of managers, with respect to their education level. Despite this, in the persuasive style, a significant difference was observed between managers with respect to their education level. Managers with a bachelor's degree have used the persuasive style more than the other styles. Also, a significant difference was observed between the participative and delegate styles of managers with respect to their education level. The managers, with the degrees higher than the master's degree, have used the participative and delegative styles more than the other styles. These results conform to the findings of Van Engen and Willemsen (2004) and Kolaric (2005), who found that there are different relationships between the managers' leadership styles and some of their personal traits. In addition, it is in agreement with the work of Mahboudi (2006), who indicated that there is a significant difference between the managers' education level and effectiveness. The results do not conform to the results of Wafa et al. (2005) and Davis (2002), who expressed that there is no significant difference between the managers' education level and their effectiveness and leadership style.

Moreover, the findings of the third hypothesis exhibited that there is a significant difference between the managers' directive, persuasive, participative and delegative leadership styles and their years of work experience. The managers, with 1-10 years of work experience, have used the directive and persuasive styles more than the other styles. In addition, the managers with more than 20 years of work experience have used the participative and delegative styles more than the other styles. These results conform to the findings of
Van Engen and Willemsen (2004) and Kolaric (2005), who indicated that there are different relationships between the managers' leadership styles and their personal traits. In addition, it is in conformity to the work of Kolagari, Modanloo and Behnampor (2007), who found that experience affects the managers' performance.

Findings of the fourth hypothesis indicated that there is a significant difference between the directive, persuasive, participative and delegative leadership styles of the managers, graduated from the Management major and those from the other fields. The managers from the other fields utilised the directive and persuasive styles more than the managers from the Management major. Most of the managers graduated from the Management major have used the participative and delegative styles more than the other styles. These results conform to the findings of Mahboudi (2006), who found that there is a significant difference between managers' field of study and effectiveness. Moreover, it is in conformity to the research of Ziraki (1997), who concluded that the managers who graduated from the Management and Planning fields of study, compared to their peer group, have a better performance in the skills for exploitation of resources, decision making, innovation and accountability. Added to that, these results do not conform to the results of Hamidi and Shoghli (2006), which shows that there iSSs no significant difference between the performance of the managers who graduated from the Management major and the managers of other fields, in nine roles of evaluation, group leadership, organisation, teachers' consultation, coordination, educational planning, decision making, service provision, management and supervision. Also, they do not conform to the findings of Ettehadnejad (2001), who concluded that in teachers' view, managers' field of study does not affect their effective skills, and also Wafa et al. (2005), who mentioned that no significant difference is observed between the managers' field of study and their effectiveness.

Given the research results, university heads are recommended to hold in-service courses for managers, who have lower education level and work experience and have been graduated from the fields of study other than the Management major. They are also recommended to pay enough attention to the managers' field of study and management background at the time of recruitment.

\section{Acknowledgements Competing interests}

The authors declare that they have no financial or personal relationships that may have inappropriately influenced them in writing this article.

\section{Authors' contributions}

J.A. and Z.M. designed the study. J.A. and Z.M. carried out the experiments. F.A., A.A., J.S-R. and A.B. analysed the results. J.A. and Z.M. wrote the article and J.S-R. reviewed critically the manuscript. 


\section{References}

Alagheband, A. (2006). The theoretical foundations and principles of educational administration. Tehran: Mental Publication.

Bennis, W. (1999). The end of leadership: Exemplary leadership is impossible without full inclusion, initiatives, and cooperation of followers. Organizational Dynamics, 28, 71-79. https://doi.org/10.1016/S0090-2616(00)80008-X

Davis, D.J. (2002). An analysis of the perceived leadership styles and levels of satisfaction of selected junior college athletic directors and head coaches. The Sport Journal, 5, 13-17.

Ettehadnejad, S. (2001). According to the teachers about the skills of effective managers and its relationship academic achievement of high school students in Shiraz. MSc dissertation. Iran: Shiraz University.

Gharaeini, K., \& Abbaszadeh, S. (2009). The relationship between leadership styles and burnout Urmia high school teachers in the academic year 85-86. Journal of Education, 3, 109-132.

Griffin, R., \& Moorhead, G. (2011). Organizational behavior. (M. Alvani \& T. Memarzadeh, Gh., Trans.). Tehran: Morvarid Publication.

Hamidi, Y., \& Shoghli, A. (2006). Essential skills in the effectiveness of quality management at the University of Medical Sciences. Payesh Journal, 5, 289-294.

Hasanian, M. (2004). Leadership styles of educating departments' managers in medica science university of Hamadan. Iranian Journal of Medical Education, 4, 108-112.

Hersey, P., \& Blanchard, K. (2005). Organizational behavior management (human resources application). Tehran: Amir Kabir Publishing Institute.

Hyler Linda, R. (1993). Leadership styles of secondary and elementary schools administrators in selected demographic variable. PhD, UCLA (University of California, Los Angeles, CA).

Jafari, E., \& Yusufnejad, F. (2002). Comparing the performance of high school principals in Isfahan and its relationship with the leadership style relationship-oriented task-oriented. Journal of Knowledge and Research in Psychology, 13, 25-38.

Khaksar, R. (2002). To evaluate the effect of organizational climate on effective behavior management school for boys and girls high school teachers in the city of Ardabil of view. MSc, Tarbiat Moallem University.
Khalkhali, A., Shakibaei, Z. \& Andesh, M. 2011. Meta-analysis on the impact of ICT on teachers professional development. Information and Communication Technology in Educational Sciences, 1, 165-183.

Kolagari, S.A., Modanloo, A., \& M.Behnampor, N. (2007). Compare specialized agricultural education administrators and medical universities in the province Alerts impact of management concepts on performance management. Journal of Agricultural Sciences and Natural Resources, 4, 158-168.

Kolaric, B. (2005). An examination of coaches and their efforts to maximize team cohesion and team satisfaction. Department of Psychology senior Thesis. Goffstown, NH: Saint Anselm College.

Mahboudi, M. (2006). The relationship between organizational skills, time management and organizational effectiveness District 2 Middle School in Shiraz. Master's Thesis. Iran: Shiraz University.

Mirsepasi, N. (2005). Application of appropriate theory in effective use of human resources. Tehran: Islamic University.

Nooraee, T., Amirtash, A., Tondnevis, F., \& Behrangi, M. (2006). The relation between educational philosophy, leadership style of managers and organizational atmosphere in colleges and departments of physical education. Journal of Movement Sciences and Exercise, 1, 37-52.

Robinson, C.T. (1996). School effectiveness behaviours of elementary school principals in Mississippi. Ph.D. Thesis. Jackson, MS: Jackson State University.

Robinson, S. (2010). Primary headteachers: New leadership roles inside and outside the school. Educational Management Administration \& Leadership, 39, 63-83. https://doi.org/10.1177/1741143210383899

Sheikh Nezami, Z. (1997). Compared self-directedness and its dimensions among managers of Shiraz high schools. Master's Thesis. Iran: Shiraz University.

Van Engen, M.L., \& Willemsen, T.M. (2004). Sex and leadership styles: A meta-analysis of research published in the 1990s 1. Psychological Reports, 94, 3-18. https://doi. org/10.2466/pr0.94.1.3-18

Wafa, S.A., Ramaya, T., \& Hoon, L.H. (2005). Leadership behaviour and effectiveness among secondary principals in Penang. Journal Ramaya $7-9$.

Ziraki, M. (1997). Compare the performance of executives and managers are graduates of educational administration graduate high school boys in Mashhad other disciplines. Master's Thesis. Iran: Shahid Beheshti University. 